Article received on $15^{\text {th }}$ March 2010

Article accepted on $31^{\text {st }}$ January 2011

UDK: 783:271.2

784.4

\author{
Euđen Činč* \\ Preschool Teacher Training College \\ 'Mihailo Palov' in Vršac
}

\title{
MELODY AS AN ELEMENT OF STUDY OF FOLK MUSIC INFLUENCE ON ROMANIAN BANAT CHURCH SINGING
}

\begin{abstract}
The existence of certain common characteristics of ecclesiastical singing in Banat and folk music, in its authentic form, usually is not considered a surprise. Noticed long time ago, it is a reality in the sphere of polyphony, harmony elements and in the domains of ornamentation and interpretation style. The mentioned similarities are evident after the analysis of representative books of collected songs and, of course, in the way church singers interpret the songs. This is the moment when unconsciously the concept of ornamentation and musical material enrichment steps on the scene.
\end{abstract}

Key words: oral mastering, interpretation style, books of collected songs, church singers.

Апстракт: Постојање видљивих утицаја народне музике на румунско православно црквено појање у Банату, уочено је пре много година. Значајна имена румунске музичке историје међу којима Тиберију Бредичану (Tiberiu Brediceanu), Теренцијус Бугарију (Terențius Bugariu), Георге Чобану (Gheorghe Ciobanu), истакли су без сумње, да поменути утицаји постоје. Они међутим никада нису до краја били истражени. Тако овај рад, као и вишегодишња истраживања на просторима српског и румунског дела Баната, из којих он и произилази, покушава да да̂ скроман допринос једној доста интересантној тематици која превазилази границе наше земље.

Кључне речи: усмени начин учења, збирке песама, интерпретација, црквени појци.

* Author contact information: eugencinci@gmail.com 
The idea about folklore influences on the church music from Banat is not just a mere speculation. More researchers, renowned names of the Romanian musical world among which we only remember the name of professor Gheorghe Ciobanu, have approached the possibility of the existence of some influences of the folklore upon church music from Banat. ${ }^{1}$

The researchers of the clerical music from Banat cannot be extracted from the context in which the Romanian Orthodox Church from here has existed for centuries. The conditions in which the orthodoxy from Banat (especially Romanian orthodoxy) carried on its activity were very difficult. One of the key moments for the orthodoxy from Transylvania, with a great impact on Romanian people and implicitly on the Romanian clerical canticle, was coming under the jurisdiction of the bishops from Karlovci. The Romanian-Serbian religious cohabitation had a great influence upon clerical music in the context of the present study. Some historians affirm the strong points of the periods of religious cohabitation. Thus, Victor Neumann writes about the modernist ideas, brought by the French Revolution, that spread among the orthodox population from the Empire due to some brilliant bishops like the great metropolitan Stevan Stratimirović. In the time of metropolitan Stevan, Andrei Şaguna (1808-1873), a young theologian and a graduate of the Theological Seminar from Vršac, the one to become the leader of the movement of independence in the Romanian church, was named bishop in Ardeal, being ordained at Karlovci. ${ }^{2}$ In the localities with mixed Serbian and Romanian population, the majority ethnic group, whichever that happened to be, has kept the ancient cult places, and the minority were obliged to build a new church. The phenomenon was present in a large number of places in both present-day Serbian and Romanian parts of Banat. The process of church separation marked the 1860s, 1870 s and even 1880s. In the process, the canonical jurisdiction was changed, so that the Romanians established their own episcopate in Caransebeş to include the Romanians of the present-day Serbian Banat. The phenomenon appeared even in Vršac, the residence of the Serbian bishop of Banat, where the Romanians have left the Episcopal Cathedral in which, according to some data until that moment, the preachers sang in Serbian and in Romanian too. Many decades passed until the Romanian population could organize and build a church. ${ }^{3}$ Namely, very few

\footnotetext{
${ }^{1}$ Ciobanu, Gheorghe. Studii de etnomuzicologie şi bizantinologie, vol. II, Bucureşti, Editura Muzicală, 1979.

${ }^{2}$ Păcurariu, Mircea. Politica statului ungar față de Biserica românească din Transilvania în perioada dualismului 1867 - 1918. Sibiu, Editura Institutului Biblic şi de Misiune al B.O.R., 1986.

${ }^{3}$ Popi, Gligor - La catedrala sârbească din Vârşeț serviciul religios se săvârşea şi în limba română. Vârşeț, Dealul Vârşețului, anul I, nr. 3, pag. 2.
} 
Romanians in Vršac at the time, mostly intellectuals and prominent peasants will build their own temple not before than the first decade of the $20^{\text {th }}$ century. Romanian orthodox temple in Vršac was consecrated in 1913, with the episcope of Caransebeş, to become the first Romanian patriarch Miron Kristea, serving the Saint hierarchal liturgy. What also seems significant for us is that the well-known Romanian choir from Lugoz was singing at the ceremony of the temple consecration, conducted by even more famous Romanian composer Jon Vidu. On the occasion Vidu was presented with a collection of Serbian songs he later harmonized.

We certainly remember Gheorghe Ciobanu who approached the problem of voices to understand better the differences that exist between the clerical canticle from Moldavia, Muntenia, Dobrogea, Oltenia and the clerical music from Ardeal and Banat. The differences between psalmist music and the music present in Ardeal and Banat can be explained by including the secular elements, different from the clerical atmosphere, in the music from Ardeal and Banat. ${ }^{4}$ These elements, according to Gheorghe Ciobanu, are nothing but folklore particles that contributed to the creation of a specific Banatian variant of clerical music, or even to the forming of a Banat style close to the soul and mind of the people from Banat. Regarding the differences between the clerical canticle and the various hierarchies from Banat, phenomenon present until nowadays, professor Ciobanu says that these are due to the maintenance of some old modal forms, on one hand, and on the other to the ulterior contacts with the folklore and with the indigenous creation and the creation of neighbouring peoples. ${ }^{5}$

Besides the deliberations about the establishing of the differences between clerical music from the Romanian countries and the clerical music from Ardeal and Banat or the deliberations about the implications of folkloric music in the lectern canticle from Banat, the professor and musicologist Gheorghe Ciobanu is interested in one more field: the semblances between Romanian and Serbian music. This aspect also intrigued another great musician, Timotei Popovici, clerical music teacher from Sibiu, who affirms that the Serbian clerical music may be found in Banat and Ardeal and explains that by the common clerical hierarchy to which the Romanians and Serbs from those places subdued for many years. Terențius Bugariu also confirms that for Serbian people as well as for the dioceses of Ardeal and Caransebeş, the canticles are common because the entire clerical canticle was brought from the Greek people through Serbian and Russian peoples. Another Romanian musical personality intrigued by the church canticle from

${ }^{4}$ Ciobanu, Gheorghe - Muzica bisericească la români, Biserica ortodoxă română, nr. 1-2, 1972, pag. 162.

${ }^{5}$ Ciobanu, Gheorghe. Studii de etnomuzicologie şi bizantinologie, vol. I, Bucureşti, Editura Muzicală, 1974. 
Banat was Tiberiu Brediceanu. According to his observations in the churches from Banat, especially the urban ones and, above all, the church in Lugoj, a typical melody has been preserved, full of greatness and uplifting for soul. ${ }^{6}$

Clerical canticle, including that from Banat, also intrigued Traian Mârza. His researches refer to the links between the folk music and the clerical music, using a comparativist method to treat the issue of cadences in particular, which he considers a common point between the Byzantine music, the Gregorian music and the Balkan peoples' music. Thus Mârza discusses more models, which include the Hymn of the Birth of Jesus, noted by I. D. Petrescu, ${ }^{7}$ and some of the carols which Gheorghe Ciobanu refers to as well in one of his studies. ${ }^{8}$

One of the researches with aesthetical notes on church canticles from Banat is realized by professor Ioan Brie. He refers to the connections between clerical music from the entire territory of Transylvania and the popular music, which he approves of and even supports. In his opinion, clerical music cannot be separated from the spirit of the nation, being a refuge for a common person, escaping from the social, political or economic reality. The tendencies of evolution of clerical music, in the opinion of professor Brie, must be redirected in order to include them in the spirit of national art and to emancipate them from the tutelage of the foreign musical cultures. ${ }^{9}$

Another hint for the research of the connections between popular music and clerical music of Banat is given by the collections of clerical canticles published a long time ago. Two collections are the most representative: Clerical canticles, realized by Dimitrie Cusma, Ioan Teodorovici and Gheorghe Dobreanu, published by Metropolitan Church of Banat from Timişoara in 1980 and the eponymous collection by Nicolae Belean, a priest and a professor, published in 1995 also in Timişoara.

The book Clerical Canticles published in 1980, recognizable by its famous black covers, contains 383 pages. This book represents a work of reference in the research of church canticle from Banat as well as the clerical practice. Certainly it is not perfect and this was noticed by its authors, since its pages contain significant errors. Many times the systematization of canticles is indistinct, and the musical aspects of a hymn are given incompletely, considering that some facts are taken for granted. Although we observed some deficiencies, we must admit that the work is a step forward in the research of clerical music from Banat.

\footnotetext{
${ }^{6}$ Brediceanu, Tiberiu. Histoire de la musique roumaine en Transylvanie. Bucureşti, 1938.

${ }^{7}$ Cinci, Eugen. Opusuri muzicale româneşti. Vršac, KOV, 2006.

${ }^{8}$ Mârza, Traian - Cadențe modale finale în cântecul popular românesc. Bucureşti, Studii de muzicologie, vol. II, 1966.

${ }^{9}$ Brie, Ioan. Considerațiuni generale asupra muzicii în Biserica Ortodoxă şi cu privire specială asupra muzicii în Biserica Ortodoxă Română. (manuscris).
} 
Clerical Canticles by Nicolae Belean represent a recent attempt at systematization of clerical canticles from Banat in a form somewhat different from its predecessors. The volume appeared as a necessity, due to the author's intention to complete and perfect the publications that preceded it. The work of Belean is also the first published after the events from December 1989.

The application of the system, which we call melodic models, in the systematization of church canticle from Banat presumes the presentation of a certain canticle with a certain text as model that will be learned, after which the melody will be applied further on other texts, as the situation requests. This forms a real system, made of more melodies that group themselves and become models for other clerical canticles. Certainly, most of times this system and concept is not too precise, does not correspond with certain norms of classification that would be normal if the approach was truly scientific. In addition, because of the phenomenon of orality, the acquired models suffer changes and in most cases pass on under an altered form. Yet, the reality and the field research indicate the presence of the system on a wide area. One can easily understand that even the reference clerical books of canticles in this field are mostly systematized according to the system of melodic models and, as an argument for this, we can quote the words of one of the authors of the volumes of canticles, priest Nicolae Belean. He says in his work Clerical canticles that besides the canticles of Holy Liturgy, the psalmist version and the version from Banat, it includes the canticles MODEL for the eight voices and he adds that after their grouping will start the application of the learned melodies on the texts of holy books used in our religious services. ${ }^{10}$ Other researchers from the past also wrote about the imminence of the system of the models in the musical thinking of the church music interpreters. Although the systematization modalities differ from case to case, all these researchers recognize the existence of this principle of approaching. Thus, Terentius Bugariu speaks about the existence of the models that he names proper voice, the voice of verses and the voice of hymn. The modality of systematization affirmed by Timotei Popovici is similar to the present-day modality, existent in the church practice; it speaks about the presence of melody named proper voice, of the melody of hymn and of the melody of antiphon. To the three melodies, Dimitrie Cunțan adds the melody of ornaments (podobii).

The work offered to readers is only a small part of a broader research undertaken during 1990ies. The collections of church songs that served as a basis in the research have been mentioned. At the same time, apart from the very collections, it was necessary to make a comparison with the situation in the field, having in mind that in the great number of cases the interpretations of the church singers themselves differ from church to church, especially in regard to the situation given

${ }^{10}$ Belean, Nicolae. Cântări bisericeşti. Timişoara, Editura Mitropoliei Banatului, 1995. 
in the books of collected songs. As a consequence, the research encompassed the interpretations of a number of church singers from a number of churches from the canon territory which were at the time a part of the Romanian Banat Orthodox Metropolis. We are talking about the Episcopate of Timişoara (at the time it was the Romanian medieval state Timis), the Episcopate of Carasebeş (the medieval state Caras - Severin) The Episcopate of Arad and Hunjedor, as well as the Episcopate of Vršac, including the Romanian people from Banat. This is a present-day territory of Serbian and Romanian part of Banat. Regarding the folklore material, it originates from these regions. The examples are mostly parts of personal collections, but there are examples which are part of other studies undertaken in the region by both domestic and foreign researchers and music experts during the $19^{\text {th }}$ century. The folk melodies appearing as models for comparisons are nowadays mostly a part of the regional folklore repertoire.

Analyzing the acoustic systems and structures, and sometimes the modalities of cadence (where it is necessary to treat them together with the acoustic systems or structures), we can frequently observe a similitude between some church canticles and popular music. In some cases, the similitude is less visible when we talk about clear, compact structures, without a functional incertitude. Where the acoustic content is rich, with the coexistence of major and minor thirds from the mode's basic tone, as well as of elements of various modes (Lydian, Mixolydian, Ionic, Aeolian, Doric, etc.), we find the modified scale structure and the approaches to popular music are more obvious. ${ }^{11}$

One of the main reasons for the said approaches is the oral mode of transmission of church music, practiced in Banat for decades and even centuries. The traces of orality are visible among musical texts. The functional indifference, about which some folklore researchers from the past have spoken, is present even in the case of church music from Banat. ${ }^{12}$ The acceptance of certain sounds even if they essentially change the acoustic structure, can be noticed in the church practice. In most cases, the acoustic deviations, even if we talk about the link sound in an intonation system named "pien", or about a sound whose presence becomes prominent, passing the statute of the "pien", lead to similar structures with those that are frequently met in popular music (the Doric becomes Doric with the $4^{\text {th }}$ step raised, the Ionic tends to become Mixolydian or Lydian and the other way round).

Regarding the melodic discourse and the melodic turns, and analyzing the collections of representative canticles and the data gathered in field activities, we

\footnotetext{
${ }^{11}$ Cusma, Dimitrie; Teodorovici, Ioan - Dobreanu, Gheorghe. Cântări bisericeşti. Timişoara, Editura Mitropoliei Banatului, 1980.

${ }^{12}$ Oprea, Gheorghe. Sisteme sonore în folclorul românesc. Bucureşti, Editura Muzicală a Uniunii Compozitorilor şi Muzicologilor din România, 1998.
} 
reached the conclusion that there are many similarities at the level of the melodic turns and of the way of conducting the musical discourse between canticles practiced in the churches from Banat and the Romanian or Serbian popular music. The similitude between the Banat church canticle and the Serbian music, especially the music that originates in the region of Vojvodina (Serbia), does not surprise us if we remember the common past which the Serbs and Romanians from these parts shared not only on the religious level but also in the social and cultural area. Near Novi Sad in the present Vojvodina there is Sremski Karlovci, the centre of the orthodox spirituality and the head of hierarchies that held jurisdiction over the Romanians and the Serbs during the Habsburg Empire and later Austro-Hungary. It is impossible to believe that the local folklore from Srem or from the entire present Vojvodina did not influence the church music of the singers from those regions, spreading later in the orthodoxy from the Empire.

Talking about the acoustic structures and systems, we stated that the church interpreters usually keep the original acoustic content, present in the collections of canticles. In that framework, the church interpreters manifest their creativity very strikingly, performing the melodic lines according to their own ideas. We could notice many interpretative variants of melodies in some voices, hence we focused our attention to those interpretations that surely lead the melodic discourse to popular music. In most of the cases, interpreters do not keep the melodic turns in their performances. The creativity of combining melodic snatches coming from many voices with the own creations is very prominent (Annex I).

A way of ornamentation specific to the popular melodic from Banat, noticed by Romanian researchers and transposed to the church music, is represented by simple and multiple melodic passages. ${ }^{13}$ The phenomenon can be observed especially in the situations in which the interpreters, from various reasons, choose melodic improvisations. We must only remember the examples of the melodies from Podobii, often essentially modified by interpreters. The vibrato is present in the interpretation of the cadence sounds as well as during the melodic discourse, being an important form of writing the melody. The impression created by the vibrato sonorities belongs more to the sphere of the folklore than to the origins of Byzantine music.

The similarities between the canticles practiced by the Serbian Orthodox Church and the canticles practiced within the Romanian Orthodox Church from Banat are evident. They are also confirmed by the people from the bosom of Church. Thus, Nicolae Corneanu, the Archbishop of Timişoara and the Metro-

\footnotetext{
${ }^{13}$ Mârza, Traian - Contribuţii la cunoaşterea principiilor structurale ale cântecului popular vechi. Cluj - Napoca, Lucrări de muzicologie, vol. III, 1967.
} 
politan of Banat, in the Argument he signed at the beginning of The church canticles by Nicolae Belean, affirmed without reserves that the way of singing of the people from Banat is otherwise the same as the way of singing of the Serbian Orthodox Church (Annex II).

After the thorough analysis of the musical and literary elements that came from the popular creations and from the church music from Banat, we have drawn some conclusions. In a concise form, the presentation of the most important conclusions is the following one:

1. There are sure influences of the popular music on the church music from Banat;

2. The said influences refer first of all to the particulars of the Romanian popular music, but also the influences of Serbian music, usually in the areas where the contacts with that ethnic group were more emphasized;

3. In the case of the majority of compared musical and literary aspects, we could find influences of popular music;

4. In the case of acoustic systems, of acoustic structures and of modalities of cadence, there could be found several mutual aspects of the popular music and the church music from Banat, namely:

- frequent terminations on the second step of the scale;

- mobility of the defining element of the modal structure (the ambiguity of structure created by interpreters' fluid treatment of the modal structure's third step);

- apparition of the augmented second in the final cadences;

- existence of acoustic structures characteristic to the popular music, which often appear as the result of leading the musical discourse by the interpreters (the Doric transforms during interpretation in Doric with the forth step raised, the Lydian transforms in Lydian with the second step raised, specific structures of the folklore), and also the presence of the Mixolydian, Lydian-Mixolydian structures, etc., used frequently in the Romanian folklore;

- The cadence on the second step after the passing over the sixth or the first step;

- The cadence on the sixth step;

- Phrygian cadence by the passing over the augmented second;

- The relation of augmented second that creates ambiguity in the acoustic system of reference (the approaching of the cadence in these cases can be: seventh step - first step or can either be: first step - second step);

5. Regarding the melodic discourse and the melodic turns, we could observe:

- final turns with cadence on the second step after passing over the first step, modalities specific to the musical folklore of the area;

- melodic turns taken over almost literally from some widespread popular melodies from Banat; 
- the initial or final melodic turns are the very similar or identical with some turns frequent in the popular melodies from Banat;

- approaching to the popular music in the leading mode of the melodic discourse by the church interpreters and the taking over of this acoustic essence from some concrete examples of melodies popular in the area; (Annex III)

6. The elements of ornamentation and the interpretation style of the church music approach those of folklore by:

- vibrato, present in the cadence zones and in the melodic course during interpretation;

- the existence of melodic passages of the writing of melody within the discourse and in the cadence zones;

- the attribution by the church music interpreters of the elements of their own creative personalities, elements that are closer to some folkloric specifics than to Byzantine specifics. This concerns the aspects that are beyond notes, beyond the mixture of particles that form a certain interpretative style. (Annex IV)

The main reasons of the obvious influence from the popular music upon church music from Banat are the following:

- the orality - the way of handing the Banat church music down to the followers that lasted for centuries, and despite the existence of some rather well-structured collections of canticles, is still present nowadays;

- the specific historical-social conditions in which the Orthodox Church from Banat had lived its destiny in the past, especially the Serbian-Romanian cohabitation, which, for a long time, the Romanians as well as the Serbs from the domain of the Habsburg Empire (Austro-Hungary) were obliged to face;

- the elements that regard the personality of each practitioner of the church canticle (his mental and soul legacy in which the particle of folklore is printed since his first years of life, his musical aptitudes, musical knowledge, the creativity of each person) and certainly the perturbing elements (the difficulties of hearing, of voice or of memory, etc.);

- still reticent attitude that some institutions of musical education have towards the church music, especially in Banat and the way of assimilation of the church canticle in some institutions of theological education in which the approaching of music is not the most correct one, the orality being ulterior the main method of learning.

These pages - based on one hand upon of the bibliographic material and on the other hand upon the field researches made on the entire territory of Banat represent a modest attempt to find some answers and to confirm the already existent enounces from the past. The hope remains that the study will be of real use 
and that it will contribute to the research of some aspects of musical life from a space created by divinity.

\section{REFERENCES}

Belean, Nicolae, Cântări bisericeşti. Timişoara, Editura Mitropoliei Banatului, 1995.

Brediceanu, Tiberiu, Histoire de la musique roumaine en Transylvanie, Bucureşti, 1938.

Ciobanu, Gheorghe, Muzica bisericească la români, in: Revista Biserica ortodoxă română, nr. 1-2, 1972, 162.

Ciobanu, Gheorghe, Studii de etnomuzicologie şi bizantinologie, vol. I, Bucureşti, Editura Muzicală, 1974.

Ciobanu, Gheorghe, Studii de etnomuzicologie şi bizantinologie, vol. II, Bucureşti, Editura Muzicală, 1979.

Cinci, Eugen, Opusuri muzicale româneşti, Vršac, KOV, 2006.

Cinci, Eugen, Consonanțe vârşețene, Vršac, Comunitatea românilor sin Iugoslavia, 2003.

Comişel, Emilia, Folclor muzical, Bucureşti, Editura Didactică şi Pedagogică, 1967.

Cusma, Dimitrie, Ioan Teodorovici and Gheorghe Dobreanu, Cântări bisericeşti, Timişoara, Editura Mitropoliei Banatului, 1980.

Eberst, Anton, Muzički breviar grada Vršca, Novi Sad, Stojkov, 2001.

Gavrilović, Nikola, Rumuni i Srbi, Beograd, Zavod za udžbenike i nastavna sredstva, 1977.

Oprea, Gheorghe, Sisteme sonore în folclorul românesc, Bucureşti, Editura Muzicală a Uniunii Compozitorilor şi Muzicologilor din România, 1998.

Păcurariu, Mircea, Politica statului ungar față de Biserica românească din Transilvania în perioada dualismului 1867 - 1918, Sibiu, Editura Institutului Biblic şi de Misiune al B.O.R., 1986.

Popi, Gligor, La catedrala sârbească din Vârşeț serviciul religios se săvârşea şi în limba română, Vršac, in: Revista Dealul Vârşețului, anul I, nr.3, 2.

Maluckov, Mirjana, Rumuni u Banatu, Novi Sad, 1985.

Mârza, Traian, Cadențe modale finale în cântecul popular românesc, Bucureşti, Studii de muzicologie, vol. II,1966.

Mârza, Traian, Contribuții la cunoaşterea principiilor structurale ale cântecului popular vechi, Cluj - Napoca, Lucrări de muzicologie, vol. III, 1967.

Mirković, Lazar, Pravoslavna liturgika ili nauka o bogosluženju pravoslavne istočne crkve, Sremski Karlovci, 1918,1920.

Mokranjac, Stevan, Zapisi narodnih melodija. Beograd, 1966. 
Činč, E.: Melody as an Element of Study of Folk Music Influence... (47-61)

Annex I

A) 1. Ilie Baba: The Romanian Orthodox Church (Banatsko Novo Selo - Serbia), Stihira, voice 3

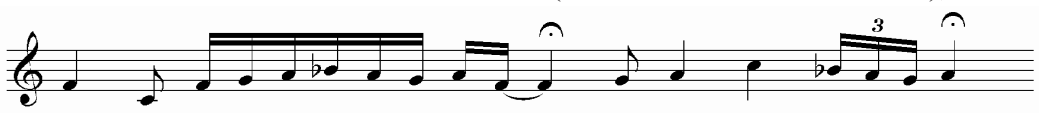

2. Mişa Nica: Doina from Nicolint (Nikolinci - Serbia)

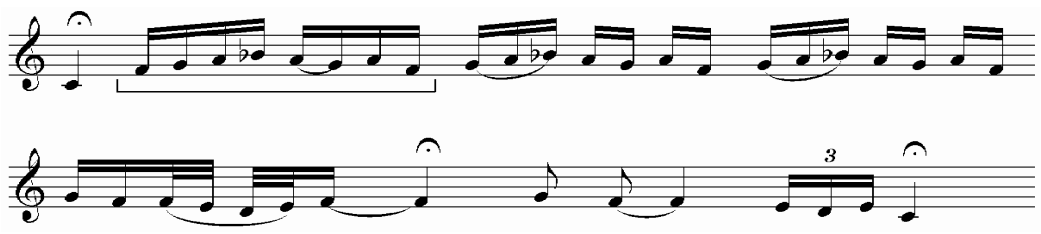

B) 1. Damaschin Banda: The Romanian Orthodox Church (Vršac - Serbia) and Ion Petroloi: The Romanian Orthodox Church (Buziaş - Romania), Stihira Stihoavnei
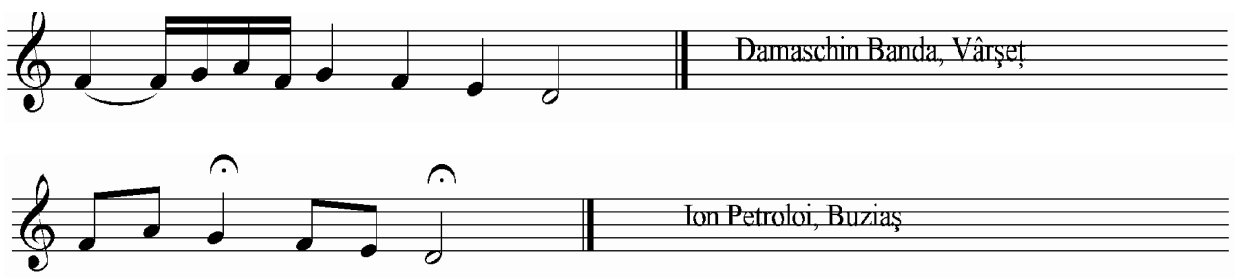

2. Ardeleană - folk dance from Banat
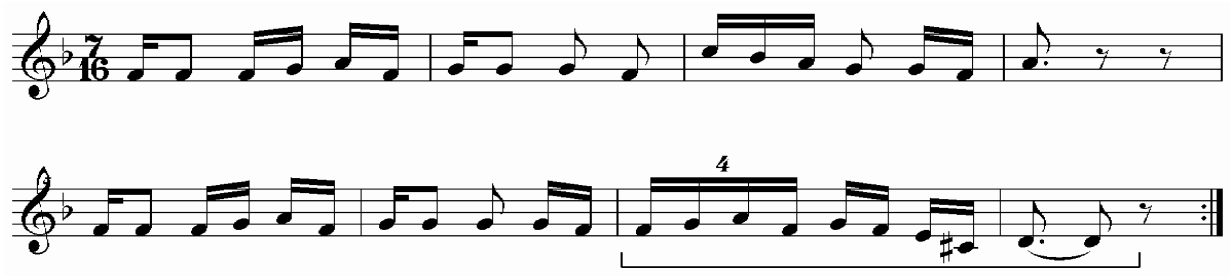

C) 1. Tropar, voice 3 (Cusma, Dimitrie - Teodorovici, Ioan - Dobreanu, Gheorghe. Cântări bisericeşti. Timişoara, Editura Mitropoliei Banatului, 1980.)

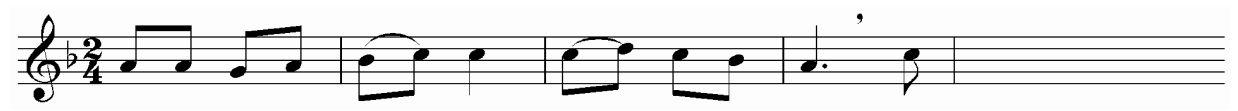

2. Mărie poale ciurate - folk dance from Banat

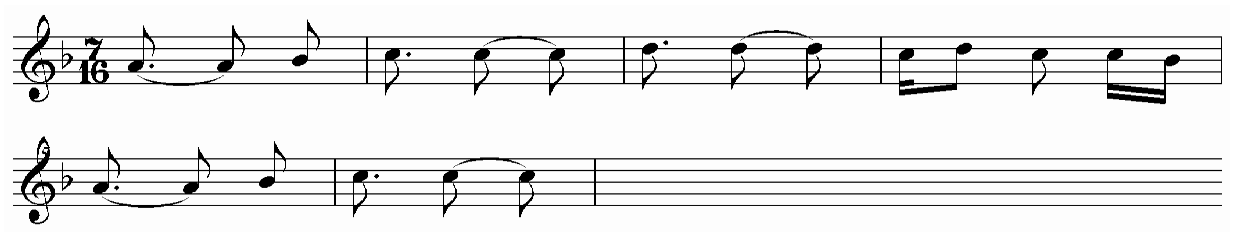

57 
Annex II.

A) 1. Axion duminical, Cusma, Dimitrie- Teodorovici, Ioan - Dobreanu, Gheorghe. Cântări bisericeşti. Timişoara, Editura Mitropoliei Banatului, 1980, p. 343.
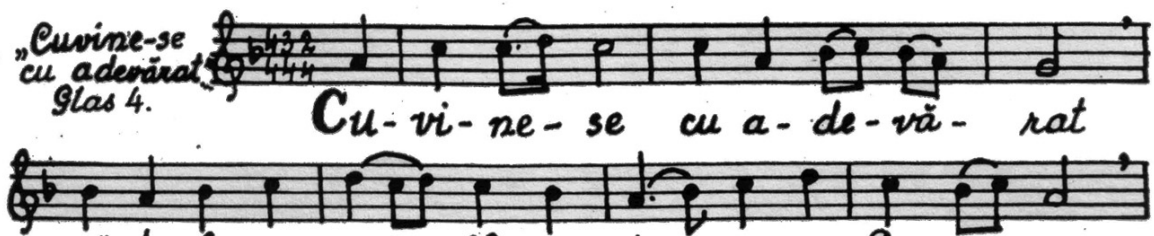

sä te fe-ri-cim, Măs-cä-toa-re de Dum-ne-xeu, से

cea pu-nu-nea fe-ni-ci-tä si preane-vi-no. द्री va_tà și_Clai_ca Dum-ne-

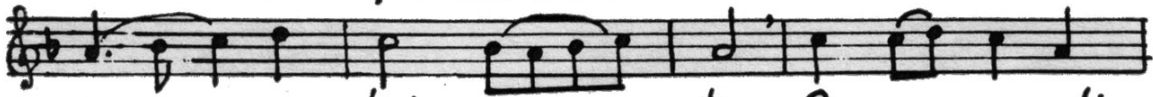
re- $u$ - hi nos- tru. Ce-sa ce poti स्र mai cins-ti_tä de-cit भle-ru-vi 然 mii si mai mă- ni-tä fă-rä de aसे se-mä-năne de-cit Se-na-fi-mii, ca-ne fä-nă के

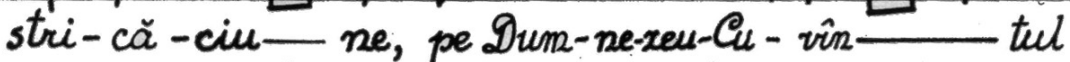

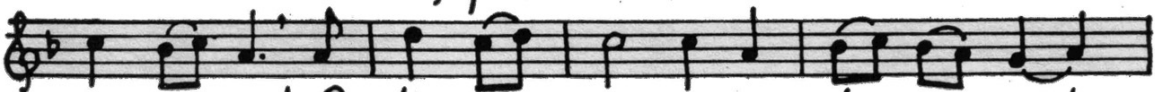

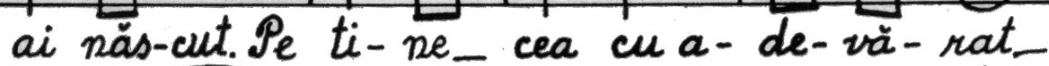
की

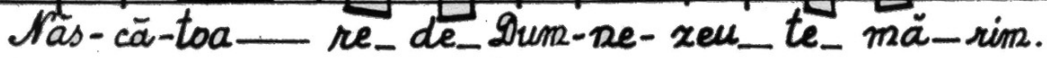
variastá:

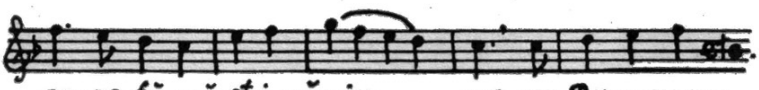

ca-re fä-nä stri-că-ciu ne, pe Dum-ne-xeu 
Činč, E.: Melody as an Element of Study of Folk Music Influence... (47-61)

2. Dostojno jest, St. St. Mokranjac, Liturgija za mešoviti hor (Beograd, Zavod za udžbenike i nastavna sredstva, 1995).
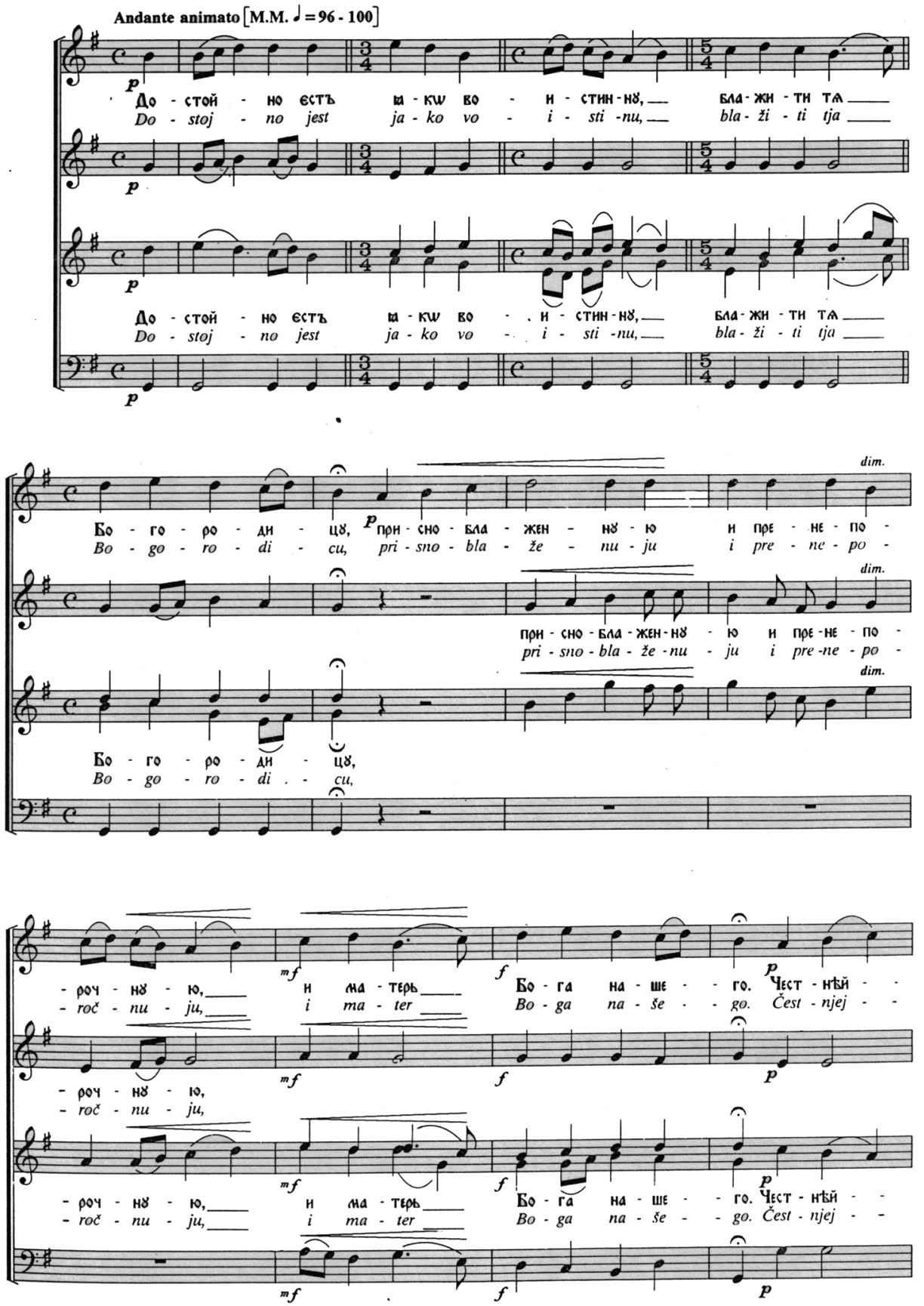


\section{Annex III}

1. Cusma, Dimitrie- Teodorovici, Ioan - Dobreanu, Gheorghe. Cântări bisericeşti. Timişoara, Editura Mitropoliei Banatului, 1980, 19.

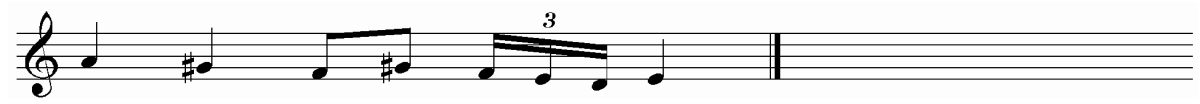

Melodic fragment from Serbian folklore

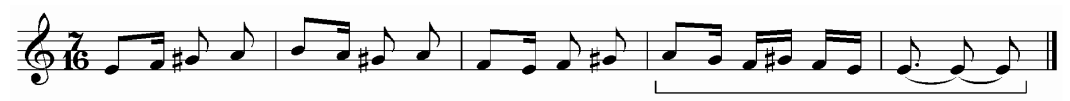

2. Cusma, Dimitrie - Teodorovici, Ioan - Dobreanu, Gheorghe. Cântări bisericeşti. Timişoara, Editura Mitropoliei Banatului, 1980, Tropar v. 1

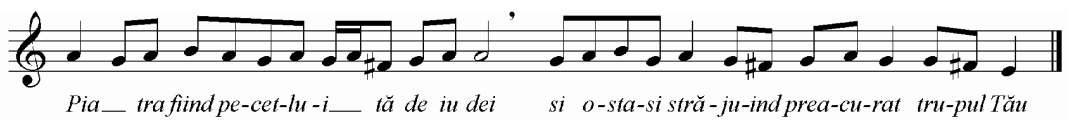

Dorul meu pe unde trece - fragment

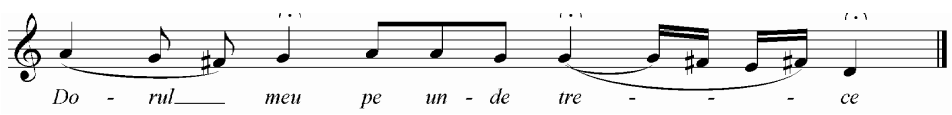

3. Interpretation, v. 3, Pavel Pajtas, Timişoara, St. Eliah’s Church

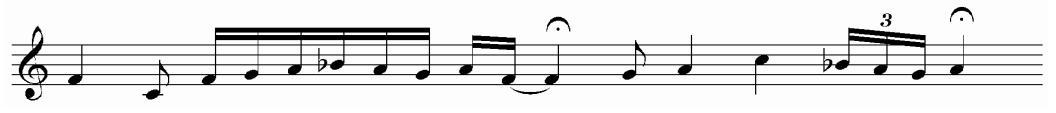

Instrumental melody (Interpretation Miša Nika, Nikolinci - Banat)
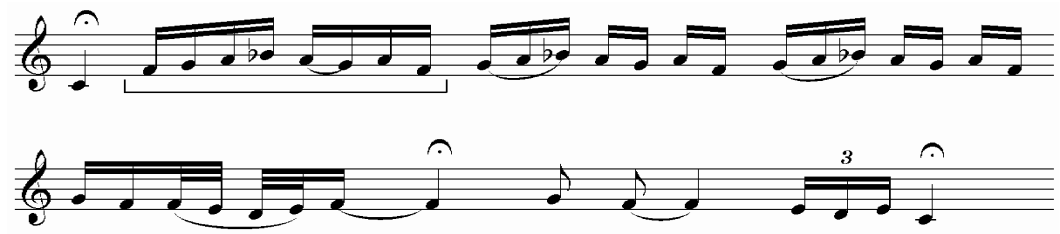


\section{Annex IV}

Interpretation Pavel Pajtas, Timişoara, St. Eliah's Church

1.

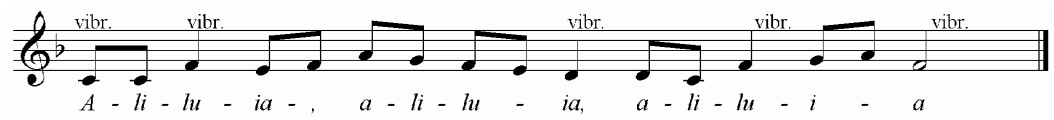

2.

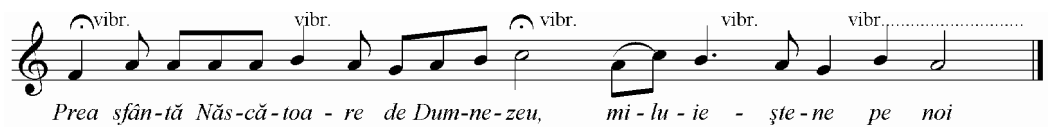

3.

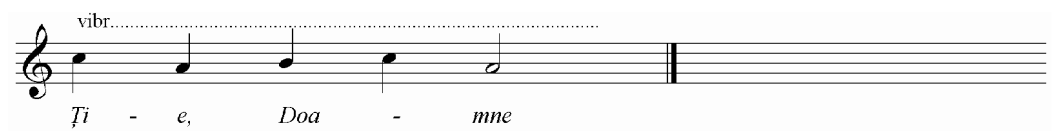

